\title{
Book Review: Al-Seghayer, Khalid 2011, English Teaching in Saudi Arabia: Status, Issues, and Challenges, Riyadh, Saudi Arabia: Hala Print CO. 175 pages, ISBN 978-6030079254
}

\author{
Ghsoon Reda (PhD) \\ Department of Applied Linguistics, Yanbu University College \\ PO box 31387, Yanbu Industrial City 510000, KSA \\ E-mail: ghsoon@hotmail.com
}

Received: $14-08-2012$

Accepted: 07-09- 2012

Published: 01-01- 2013

doi:10.7575/ijalel.v.2n.1p.221

URL: http://dx.doi.org/10.7575/ijalel.v.2n.1p.221

\begin{abstract}
In this book, Khalid Al-Seghayer offers a thorough study of the history and status of English language teaching in Saudi Arabia, highlighting deficiencies and suggesting remedies in an attempt to cure the current standards of English education, particularly in public schools which, in his own words, "have deteriorated perhaps beyond hope of recovery" (p. 95).

\section{Introduction}

In this book, Khalid Al-Seghayer offers a thorough study of the history and status of English language teaching in Saudi Arabia, highlighting deficiencies and suggesting remedies in an attempt to cure the current standards of English education, particularly in public schools which, in his own words, "have deteriorated perhaps beyond hope of recovery" (p. 95).

\section{Overview}

In the introduction to the four-part book, Al-Seghayer begins with an outline of the reasons behind the introduction of English into Saudi Arabia, showing that it was a key factor in facilitating the communication of the kingdom's visions and needs to the outside world after its establishment in the early 1930s. He then proceeds to a description of the current contexts of the language using Kachru's (1992) classical model of the three concentric circles of world Englishes. Although he considers Saudi Arabia to be among the Expanding Circle countries (where English is a foreign language), he does not exclude the possibility of considering it as a member of the Outer Circle (where it is a second language) as in certain institutions, such as those related to science, medicine and engineering, English is used as the sole medium of communication among members. He, however, points out that Saudi Arabia falls into the low proficiency (rather than the inner/high Proficiency) circle country (in Kachru's (2004) terminology).

In part I, called 'History of EFL in Saudi Arabia and its status and functions', the author concerns himself with what can be referred to as the spread of English in Saudi Arabia, starting with its early introduction into the educational system and ending with its present-time status. He brings into focus the vehicles for the presence of English in the kingdom as well as students' positive attitudes towards learning the language (being a means for personal and national growth) in order to evidence the important role the language has come to assume in the country. In the remaining parts of the book, however, he offers a detailed description of the development of English education, noting that its current standards still do not match the status and functions of the language in Saudi Arabia. He calls for immediate reform.

In part II, called 'The reality and needs of EFL teacher preparation programs in Saudi Arabia', the author reviews the past and present teacher-preparation programs offered by the English departments at various Saudi teacher-education colleges and colleges of arts. He bases his review on studies noting that although current programs rightly place more emphasis on linguistics and language skills than on literature, they are still inadequate due to the lack of a systematic approach emphasising communicative competence and linking teacher trainees to schools (see p. 22). Al-Seghayer stresses the need for prolonging the duration of language skills courses and for teacher trainees to receive additional training in teaching methods, material preparation and classroom management from in-service teachers due to the low proportion of methodology courses which "represent no more than $10 \%$ of the total courses offered by English departments in colleges and universities" (p. 20). This review is followed by a reform proposal which includes longterm and short-term plans. The long-term plan, on the one hand, involves reconsidering the study plan of the current local EFL preparation programs and establishing an EFL national training centre that provides accreditation and training (inside the country and abroad) for pre-service teachers. The short-term plan, on the other hand, includes long-term professional development programs and one-shot training programs. The professional development programs suggested are also recommended for in-service teachers since, based on the results of an unpublished study conducted by the Saudi Ministry of Education (2004), a substantial number of these teachers are "professionally and linguistically incompetent and do not have a firm grasp of the methods of teaching language elements" (P. 23). In addition, AlSeghayer notes, in-service teachers lack the incentive to develop their own professional skills as the only promotion
\end{abstract}


they get is a senior administrative position. The author suggests that professors of Applied Linguistics and ELT methods should also receive training to guarantee that "they have the necessary level and type of expertise to deliver EFL courses instead of merely focusing on disseminating teaching methods and procedural skills to traditionally deliver the course materials" (p. 26). He also suggests that English graduates should be tested and licensed before they are allowed to enter into the teaching profession. Such measures, for him, are important to ensure that the graduates receive satisfactory English education and teacher training.

In part III, called 'The structure of the EFL curriculum in Saudi Arabia', Al-seghayer provides an analysis of the structure and features of the Saudi EFL curriculum throughout its historical developmental stages. He shows that the development of the Saudi EFL curriculum between 1927 and 2004 represents a shift of attention from improving learners' reading ability to improving all their linguistic abilities, or communicative competency, through programs built on notions and functions. However, the continuous attempts of the Saudi educational authorities to improve the EFL curriculum and teaching approach, taking into account students' socio-cultural background, do not seem to have succeeded in producing proficient students, as several studies indicate (see p. 54). The author attributes the failure of the current curriculum to achieve its objectives to a number of issues that should be resolved for bringing about reform. The following are the most vital ones: 1) the lack of grading in the curriculum, 2) the lack of teaching resources, 3) the insufficient time allocated for delivering the curriculum (4 periods of 45 minutes per week), 4) the incompetency of teachers with regards to teaching methodology and test writing, 5) the adoption of a top-down model of instruction rather than a bottom-up model in which teachers play an active role in preparing materials based on students' needs and abilities, and 6) the focus of students (who lack intrinsic motivation) and school administrations on achievement rather than performance. The last point is critical because it leads English teachers to focus on preparing their students to simply pass exams. In addition, it results in a mismatch between the course objectives and teaching methodology. Saudi teachers adopt the Grammar Translation Method and the Audio-Lingual Method, which encourage a focus on repetition and memorisation of word lists and grammatical rules, to teach a curriculum that is intended to develop students' communicative competency.

In part IV, called 'Teaching English in Saudi Arabian schools and institutions', the author offers a more detailed description of English education in Saudi Arabia, starting from preschool level and ending with graduate level. He sheds more light on the factors (mentioned in part III) affecting English education, but adds a critique of the final examination content and evaluation scheme used in schools showing that they do not assess students' abilities but basically help them to pass the final examination. He finishes this part by stressing the need for raising the standards of English education through strict teacher assessment and recruitment procedures.

\section{Discussion and conclusion}

This study draws a detailed picture of English education in Saudi Arabia which makes it a very good resource for researchers interested in the situation. In addition, the suggested reforms target all deficiencies. However, two important issues need to be addressed in this regard. One issue is that the reforms are not phased which can create dilemmas in their application. For example, the main recommendation for reforming teacher-preparation programs is linking them to schools where the major problems with English education are shown to reside. If a substantial number of in-service teachers are incompetent, then any training received from such teachers will do more harm than good to teacher trainees. In addition, the top-down model of instruction adopted in schools will be an obstacle to teacher trainees' attempts to put into practice the teaching methodology they learn in college. In fact, teacher trainees often question the need for learning teaching methodology they will not need to use in the English classroom as they will simply deliver prescribed materials. No reform can take place if these ailments are not cured before any attempt is made to establish a systematic link between schools and teacher-preparation programs. There is no suggestion in this study that this should be the case. Relevant to this is the recommendation for replacing the top-down model of instruction with a bottom-up model. There is no indication in this study that this should happen after teachers have undergone the necessary training, considering their pointed out incompetencies.

A second issue related to the suggested reform figures in the failure of the author to draw on the current situation of education in the West where the textbook is replaced by course objectives and teacher-prepared materials that are tailored to students' needs and abilities. There is no recommendation for adopting the Western style of education either on school or college level. No matter what changes are introduced to the EFL curriculum or the study plans of the current teacher-preparation programs, the use of a textbook according to a prescribed pacing schedule, which is the case in Saudi schools and colleges of education, is harmful in the sense that teachers may focus more on covering the textbook materials according to the prescribed pacing schedule than on ensuring that effective teaching and learning are taking place. This leads to the point that ensuring quality education requires good teaching, and good teaching needs to be based on objectives that meet students' needs, and not on textbooks. No training can guarantee good applications if teaching a course would continue to mean using a certain textbook(s). Had the author taken these points into account, he would have produced a better quality work.

\section{References}

Kachru, B. (1992). The second diasporas of English. In T. Machan and C. Scott (Eds.), English in its Social Contexts: Essays in Historical Linguistics (pp. 230-252). New York: Oxford University Press. 